\title{
Katılım Bankacılığında Uygulanan Finansal Kiralama Yöntemindeki Risk Faktörünün İslam Hukuku Açısından Değerlendirilmesi*
}

\author{
Temel KACIR
}

Özet

Katılım bankalarının finansman enstrümanlarından biri olan finansal kiralama klasik dönemde mevcut olmayıp son dönemlerde ortaya çıan akit çeşitlerindendir. Kira süresinin sonunda mülkiyetin müşteriye nakli ile sona eren finansal kiralama; menfaatin temliki yönüyle kira akdini, malın bedelli ya da bedelsiz temliki yönüyle ise satış veya hibe akdini kapsamaktadır. Fıkhî tasavvuruna bağlı olarak farklı değerlendirmelere tabi tutulan finansal kiralama bazı yönleriyle tartışılmaya devam etmektedir. Bu tartışmalardan biri kazançtan elde edilecek kârın meşruiyetine etki eden risk faktörüdür. İslam hukukunun ilkelerini referans alan Katılım bankaları müşterilerine fon kullandırırken yani finansman sağlarken bunu salt finansal bir faaliyet değil, ticari bir faaliyet olarak gerçekleştirmektedirler. Dolayısıyla Katılım bankalarının fon kullandırma yöntemleri arasında yer alan finansal kiralamada riski üstlenmeleri önem arz etmektedir. Bu sebeple Katılım bankalarının finansal kiralama sözleşmelerinin bu yönüyle incelenmesi kayda değer bir konudur. Katılım bankalarının "Finansal Kiralama" sözleşmelerindeki risk faktörünü analiz ettiğimiz bu çalışmada, söz konusu bankaların risk faktörünü yüklenmedikleri sonucuna ulaştık.
Anahtar Kelimeler

Katılım Bankacılığı

Finansal Kiralama

Kira Akdi

Satış Akdi

Risk

\section{Makale Hakkında}

Geliş Tarihi: 29.06.2020

Kabul Tarihi: 02.09.2020

Doi: 10.18026/cbayarsos.759995

\section{Evaluation of the Risk Factor in the Financial Leasing Method Applied in Participation Banking in terms of Islamic Law}

\section{Abstract}

Leasing, one of the financial instruments of participation banks, is a recent contract not existing in the classical period. The leasing that ends with the transfer of ownership to the customer at the end of the lease term comprises the lease contract with the aspect of the assignment of interest and the sale or the grant contract with the aspect of the assignment of goods by payment or without payment. The leasing has been the subject to different assessments correspondingly its imagination at the Fiqh and has been discussed in some aspects of it. One of these discussions is related to the risk factor affecting whether the profit is valid. Participation banks, which take the principles of Islamic law as a reference, realize the funding not only as a financial activity but as a commercial activity while providing funds to their customers. So it is important for participation banks to assume the risk in financial leasing, which is one of the lease-based funding methods. Thus, it is noteworthy that the lease agreements of participation banks are examined in this aspect. In this study, in which we analyzed the risk factor in the "Financial Leasing" contracts of the participation banks, we examined that the banks did not undertake the risk factor.
Keywords

Participation Banking

Leasing

Lease Contract

Sales Contract

Risk

\section{About Article}

Received: 29.06.2020

Accepted: 02.09.2020

Doi: 10.18026/cbayarsos.759995

\footnotetext{
* Bu makale Manisa Celal Bayar Üniversitesi'nde BAP kapsamında hazırlanan 2018-168 nolu projenin bir çıktısıdır.

** Dr. Öğretim Üyesi, Manisa Celal Bayar Üniversitesi, İlahiyat Fakültesi, İslam Hukuku Ana Bilim Dalı, temel_kacir@hotmail.com ORCiD: 00000001-5679-280X
} 


\section{Giriş}

Faizsizlik prensibini altın kural olarak kabul eden Katılım bankaları, her türlü finansal faaliyet ve işlemlerini İslami kurallar çerçevesinde yürütmeyi kendilerine ilke olarak belirlemişlerdir. $\mathrm{Bu}$ ilkeler doğrultusunda Katılım bankaları müşterilerine finansman sağlarken bunu salt finansal bir faaliyet olarak değil, ticari bir faaliyet olarak gerçekleştirmektedirler. Bu durum Katılım bankalarının finansman faaliyetlerinin varlıkla yani mülkiyetle desteklenmesini zorunlu kılmaktadır. Bu varlığın riskine katlanmak ise kazancın meşruiyetine etki eden en önemli faktördür.

Katılım bankalarının kiraya dayalı fon kullandırma yöntemlerinden olan finansal kiralamada akde konu olan malın mülkiyet hakkı kira süresince mal sahibi olan bankaya, menfaatinden istifade etme hakkı ise kiraciya aittir. Bu nedenle mal sahibi olan bankanın akit süresince kiraya konu olan aynı kullanmaya hazır tutması ve kiracının o ayndan yararlanmasını engelleyen eksiklik ve kusurları gidermesi diğer bir ifadeyle mülkiyetin riskini üstlenmesi gerekmektedir.

Katılım bankacılığında uygulanan finansal kiralama yöntemindeki risk faktörünün İslam hukuku açısından değerlendirilmesini konu edinen bu çalışmada, öncelikle finansal kiralamaya yönelik fikhî tasavvurlar kısaca ortaya konacak ve bu tasavvurlar üç görüş üzerinden risk faktörü yönüyle incelenecektir. Böylece Katılım bankalarının finansal kiralamada riski üstlenmelerinin niçin gerekli olduğuna dair bir zemin oluşturulmuş olacaktır. Daha sonra Katılım bankalarının finansal kiralama sözleşmeleri risk faktörü yönüyle İslam hukuku açısından değerlendirilmeye tabi tutulacaktır.

\section{Risk Faktörü Yönüyle Finansal Kiralama}

Malın mülkiyetinin müşteriye intikali ile sonlanan finansal kiralama yöntemi İslam dünyasına 1970'li yıllarda girmiştir. Finansal kiralama, vadeli satışlarda son taksiti tahsil edinceye kadar malın mülkiyetini müşteriye intikal ettirmeyerek malın bedelini garantiye alması yönüyle satıcıya, satın alma imkânı olmadığı durumlarda ya da var olan sermayesini satın alacağı mala bağlamaması yönüyle alıcıya önemli avantajlar sağlamaktadır.

Finansal kiralama 6361 nolu 13.12. 2012 tarihli Finansal Kiralama, Faktoring ve Finansman Şirketleti kanununda; "Bir finansal kiralama sözleşmesine dayal olmak koşuluyla, bu Kanun veya ilgili mevzuatı uyarınca yetkilendirilen kiralayan tarafından finansman sağlamaya yönelik olarak bir malın mülkiyetinin kira süresi sonunda kiracıya devredilmesi; kiractya kira süresi sonunda malın rayiç bedelinden düşük bir bedelle satın alma hakkı tanınması; kiralama süresinin malın ekonomik ömrünün yüzde sekseninden daha büyük bir bölümünü kapsaması veya finansal kiralama sözleşmesine göre yapılacak kira ödemelerinin bugünkü değerlerinin toplamının malın rayiç bedelinin yüzde doksanından daha büyük bir değeri oluşturması hâllerinden herhangi birini sağlayan kiralama işlemidir" şeklinde tanımlanmaktadır.

İslam hukukunda ise, fikhî tasavvuru farklılık arz eden bu akdin tanımı hususunda günümüz İslam hukukçuları ve araştırmacıları arasında bir birliktelik sağlanamadığı görülmektedir. Uygulamayı muhatabın zihnine yaklaştırma amacına yönelik farklı tanım denemeleri yapılmış olsa da yapılan tanımlar tenkitten kurtulamamıştır. Zaten finansal kiralamaya yönelik fıkhî tasavvurlar göz önünde bulundurulduğunda efradını cami` ağyarını mani` bir tanım yapmak oldukça da zor gözükmektedir. Finansal kiralamaya yönelik farklı tasavvurların en önemlileri ise şunlardır. 
a. Kira akdi tamamlandıktan sonra, hakiki ya da sembolik bir fiyatla satış vaadinin bu akde dâhil edilmesi durumu.

b. Kira akdi tamamlandıktan sonra, hibe vaadinin müstakil olarak bu akde dâhil edilmesi durumu.

c. Kira ve satış akdinin aynı anda kurulması durumu.

d. Kira akdiyle birlikte, satım akdi için kiralayan lehine -süresinin en son kiranın ödeme vakti olan- şart muhayyerliğinin ileri sürülmesi durumu.

e. Kira akdiyle birlikte mal sahibinin kiracıya, dilediği zaman -bağımsız olarak gerçekleştirmesi şartıyla- malın temellüküne yönelik muhayyerlik hakkını vermesi durumu.

f. Kira akdiyle birlikte mal sahibinin kiracıya; a) kira süresi sonunda piyasa değeri üzerinden malı satın alma hakkını vermesi, b) kira süresinin belirli dönemlerle uzatılması, c) kira sonunda malı sahibine iade etme hakkını vermesi durumu.

g. Bankanın satın aldığı malı tekrar kendisine satan kişi ya da kuruma satış ya da hibe vaadiyle kiralaması durumu. (Fıkhî Tasavvurlar için bk. Karadâğî, 2000, XII/I, s. 492-494; Şeta, 1424, s. 17-29).

Fıkhî tasavvurlar incelendiğinde, tartışmaların mihverini üç ve yedinci maddelerin oluşturduğu görülmektedir. Zira üçüncü maddede iki akit aynı anda yapılmakta, yedinci madde ise îne satışını yani vadeli olarak satılan malın peşin parayla daha ucuza alınmasını içermektedir.

Menfaatin temliki yönüyle kira akdini, malın bedelli ya da bedelsiz temliki yönüyle satış veya hibe akdini kapsadığı görülen finansal kiralamaya yönelik fıkhî tasavvurları üç görüş üzerinden değerlendirebiliriz. Buna göre fıkıhta finansal kiralama; 1) Malın mülkiyetinin hakiki ya da sembolik bir fiyatla müşteriye intikal etmesi yönüyle vadeli satıştır. 2) Müşterinin belirli taksitler karşılığında malın menfaatinden istifade etmesi ve bu süre içerisinde mal üzerinde mülkiyetin intikaline yönelik hiçbir işlem yapamaması yönüyle kira akdi olarak başlayan daha sonra başka bir akitle mülkiyetin intikali sağlanan mürekkeb bir akittir. 3) Satış ve kira akitlerden müteşekkil yeni bir akittir.

"Akitlerde asıl olan maksatlardır lafızlar değildir" (Mecelle md. 3) kuralını delil alan bazı araştırmacılar (bk. Şazelî, 1998, V/IV, s. 2656-2657; Abdullah, 2000, XII/I, s. 2599-2602; Bayındır, 2005, s. 147-151) temlik ile sonlanan ve tazmin sorumluluğunun kiralayandan kiracıya intikal ettiği bu akdin vadeli satış akdi olduğu görüşündedirler. Ancak vadeli satışa benzeyen bu akdin vadeli satıştan yapısal olarak tamamen farklı olduğu, zira finansal kiralama iki akitten yani kira-satış veya satış vaadi ya da kira-hibe veya hibe vaadi akitlerinden oluştuğu halde vadeli satışta bu özelliğin bulunmadığı ve yine bu akitte fiyat farkı, kira bedeliyle birlikte uygun olacak şekilde vadeli hale getirilmekte iken vadeli satışta fiyatın, vade zamanına göre tespit edildiği ifade edilerek bu görüş tenkit edilmiştir. (Karadâğ̂̂, 2000, XII/I, s. 477; Zuhaylî, 2002, s. 395-396). Ayrıca bu görüş tazmin sorumluluğu yönüyle de tenkit edilmiştir ki bunun detayı üçüncü görüş kapsamında ele alınacaktır.

Başta İslam Fıkıh Akademisi, Faizsiz Finans Kuruluşları Muhasebe ve Denetim Organizasyonu (AAOIFI) ve Kuveyt Finans Denetim Kurulu olmak üzere finansal kiralamanın meşru olduğuna fetva veren kurumlar ile birçok İslam hukukçusu ve 
araştırmacısı bu akdin kira akdi temelli bir akit olduğu görüşündedir. Zira finansal kiralamada müşteri, belirli taksitler karşılığında malın menfaatinden istifade etmekte ve bu süre içerisinde mal üzerinde mülkiyetin intikaline yönelik herhangi bir işlem yapamamaktadır. İkinci akit ise ancak kira akdi tamamlandıktan sonra ayrı bir akit olarak devreye girmektedir. Aynı zamanda bu görüşe göre finansal kiralama, salt bir kira akdi de değildir. Zira kira akdinde temlik söz konusu değilken finansal kiralama genellikle temlik ile sonuçlanmaktadır. Yine ikinci akdin türüne göre kira bedeli normal bir kira bedeli de değildir. Dolayısıyla finansal kiralama kira süresince kira hükümlerine, daha sonra ise satış ya da hibe hükümlerine tabi olan mürekkeb bir akittir. Bu görüşe göre kiracıdan kaynaklanmadığı sürece tazmin yani akde konu olan malın telef ve hasar sorumluluğu ile malın aslına yönelik bakım ve sigorta gibi giderlerin mal sahibi üzerinde olması bu akdin meşruiyetinin şartıdır.

Finansal kiralamayı satış ve kira akdinden oluşmuş yeni bir akit olarak kabul edenlere göre bu akit ne yalnız satış akdinin ne de yalnız kira akdinin hükümlerini kapsamakta, aksine satış ve kira arası yeni bir akit türü olmaktadır. Bu görüşe göre tazmin sorumluluğu ile mala ait masrafların tamamının kiracıya ait olması bu akdin gereğidir. (Aktepe, 2013, s. 49; İnanır, 2017, III/I, s. 32). Birçok yönüyle eleştiriye açık olan bu görüş, konumuz itibariyle iki nokta açısından önem arz etmektedir. Bunlardan biri yeni bir akit olarak kabul edilen finansal kiralamanın özü itibari ile diğeri hukuki sonucu itibariyledir.

Öncelikle bu görüş özü itibariyle, "bir satışta iki satışı" (Ebû Dâvûd, Büyû, 68; Nesâî, Büyû, 60; Tirmizî, Büyû, 19) ya da "bir pazarlıkta iki pazarlığı" (Şevkânî, 1996, V, s. 170) yasaklayan hadislere aykırı gözükmektedir. Zira bu hadisin kapsamına yönelik yapılan izahlar incelendiğinde yapıları ve sonuçları itibariyle birbiriyle çelişki/tenakuz ifade eden akitlerin tek bir akitte birleştirilmesinin de bu yasağın kapsamında olduğu görülecektir. (Hammad, 2001, s. 179-188; İmranî, 2006, s. 181-185). Başka bir ifadeyle birden fazla akdin aynı zamanda aynı mahal üzerinde birleşerek tek bir akit olabilmesi, ancak birbirine zit hükümleri barındırmama şartına bağlıdır. Hâlbuki finansal kiralamada menfaatin satışı olan kira akdi ile aynın satışı olan satım akdi, tek bir fiyatla aynı anda tek bir mahal üzerinde gerçekleşmektedir. Bu durum aynın satışı olan satış akdi ile menfaatin satışı olan kira akdinin özünü etkilemektedir.

Klasik dönem kaynaklarında kira ve satım akdinin tek bir akitte toplanabileceğine dair örnekler incelendiğinde bu akitlerin, "bin liraya bu arabayı sana sattım ve bu evi sana kiraladım" sözünde olduğu gibi ya cem suretiyle, "bu evi benden beş yüz liraya kiralaman karşılığında bu arabayı bin liraya sana sattım" sözünde olduğu gibi ya da tekabül suretiyle olduğu görülecektir. (Desûkî, ts., IV, s. 5; Haraşî, 1317, VII, s. 4). Yoksa finansal kiralamada iddia edildiği gibi satış ve kira akdinin aynı anda aynı mahal üzerinde tek bir fiyatla toplanması şeklinde değildir. Nitekim İslam Fıkıh Akademisi XII. Dönem toplantısında finansal kiralamanın yasak olan şeklinin gerekçesini, birbirine zıt olan akitlerin tek bir ayn üzerinde aynı vakitte toplanması olarak ifade etmiştir. Bu durumda finansal kiralamanın meşru bir mürekkeb akit olabilmesi ancak ikinci akdin, kira akdi bittikten sonra müstakil olarak yapılması halinde mümkün olabilmektedir.

$\mathrm{Bu}$ görüşe yöneltilebilecek diğer itiraz noktası ise -tıpkı birinci görüş gibi- akitlerin muktezasına aykırı olacak bir hukuki sonucu içermesidir. İslam hukukunda kazancın meşruiyetine etki eden en önemli faktör "risk-getiri dengesi" ilkesi gereğince mülkiyetin gerekli kıldığı tazmin sorumluluğunu yüklenme mesuliyetidir. (Kacır, 2020, XXXXIV/1, s. 
139-144). Hâlbuki bu yaklaşımda mülk sahibinin sorumluluğunda olması gereken malın telef ve hasar sorumluluğu ile malın aslına yönelik bakım ve sigorta gibi masraflar, satım ve kira akitlerinin muktezasına aykırı olarak kiracıya yüklenerek akitlerin hukuki sonuçları ihlal edilmiştir. Ayrıca mülkiyetin gerektirdiği bu sorumluluk, birinci görüşün iddia ettiği gibi malın mülkiyetinin geleceği dikkate alınarak değil an itibariyle mülk sahibinin yüklenmesi gereken bir sorumluluktur. Muktezaya aykırı sonuçları içeren şartların akitlerde şart olarak dahi ileri sürülemeyeceği mezheplerin ortak görüşüdür. (Senhûrî, 1997, II, s. 106124).

Finansal kiralamanın geleneksel uygulamalarını dikkate alanlar bu hukuki sonuçların ya da şartların geçerli olabileceğini ifade etmektedirler. Zira finansal kiralama muhasebe yönüyle hizmet kiralaması -ki bu klasik kiraya tekabül etmekte- ve finansal kiralama olarak ikiye ayrılmaktadır. Kullanım ve yararlanma hakkının kiracıda bulunması yönüyle bunlar aynı olsa da finansal kiralamada tazmin yükümlülügüün̈n kiracıya intikal etmesi yönüyle klasik kira akdinden ayrılmaktadır. Dolayısıyla bu görüşe göre bu sonuç veya bu şartın ileri sürülebilmesi finansal kiralamanın yeni bir akit olması yönüyledir. (Benzer değerlendirmeler için bk. Aktepe, ts., s. 112-114; İnanır, 2017, III/I, s. 32).

Finansal kiralamada tazmin sorumluluğunun, akdin muktezasına aykırı olarak hukuki bir sonuç kabul edilmesi ya da tarafların rızasıyla ileri sürülülebilecek bir şart olarak kabul edilmesi kendi içerisinde ciddi mahzurları barındırmaktadır. Zira İslami finansı geleneksel finanstan ayırt eden en temel fark, İslami finansın bir varlık üzerinden ticari bir faaliyet olarak gerçekleştirilmesidir. Ticaret, mülkiyete dair risklerin mal sahibi tarafından yüklenilmesini gerekli kılmaktadır. İşte bu, faizi kârdan ayırt eden en temel farktır. Finansal kiralamayı yeni bir akit kabul ederek mülkiyetin gerekli kıldığı tazmin sorumluluğunu mal sahibinden alıp kiracıya yüklemek, kira konusu varlığı devre dışı bırakmak anlamına gelmektedir. Akdin hüviyetini doğrudan etkileyen bu durum finansal kiralamayı kârz akdine, başka bir ifadeyle müşteriye varlık üzerinden sağlanan finansmanı nakit üzerinden gerçekleşen bir finansmana dönüştürmektedir. Sonuçta elde edilecek kâr da faize dönüşmüş olmaktadır. (Benzer değerlendirmeler için bk. Takî Osmânî, 2000, XII/I, s. 644-645: Abadî, 2000, XII/I, s. 647-649; Karadâğî,, 2000, XII/I, s. 661; Kahf, 2000, XII/I, s. 373; Uveyda, 2010, s. 251-256). Bu nedenle finansal kiralamanın salt finansal bir meseleye dönüşmemesi ya da faiz şüphesini barındırmaması için tazmin kurallarına riayet edilmesi zorunludur. Nitekim İslam Fıkıh Akademisi ve AAOIFI başta olmak üzere birçok İslam hukukçusu ve araştırmacısı şer'î olarak izin verilen finansal kiralama akdinde mülkiyet kuralı gereği tazmin sorumluluğunun kiralayana ait olması gerekliliğini açıkça ifade etmişlerdir.

Yukarıda görüldüğü üzere finansal kiralamaya yönelik farklı yaklaşımlar söz konusudur. Ancak biz finansal kiralama sözleşmelerini, Katılım bankalarının sözleşmelerinde tarafların kiralayan/satıcı ve kiracı olarak vasıflandırılması ve kira süresinin sonunda kiracının akde konu olan malı alıp almama hakkının olması gerekçesiyle, kira akdi üzerinden değerlendireceğiz. Bu aynı zamanda konuyla ilgili hâkim olan kira merkezli yaklaşımla da uyumludur. 


\section{Katılım Bankalarının Uyguladığı Finansal Kiralama Sözleşmelerinin Risk Dağılımı Açısından İncelenmesi}

Katılım bankaları finansal kiralama sözleşmelerinde malın mülkiyetinin kendilerine ait olduğunu, kiracının ise zilyet olduğunu açıkça zikretmiş (Kuveyt Türk, FKS., 11; Vakıf Katılım, FKS., 13.1; Türkiye Finans, FKS., 13.1; Ziraat Katılım, FKS., 9.1) olmalarına rağmen sözleşmelerinin yorum ve uygulama esaslarını açılarken kendilerini yalnızca finansman sağlayan olarak ifade etmeleri sebebiyle çelişkiye düşmüşlerdir. "İşbu Sözleşmenin yorum ve uygulamasında kiralayanın, malın üreticisi, satıcısı ve sağlayıcısı olmadığı, sadece kiracının talep ettiği malın finansmanının să̆lanması amactyla mülkiyetin mevzuat gereği kiralayan tarafindan edinildiğgi ve kiracıya finansal kiralamasının yapıldı̆̆g esas alınacaktır." (Vakıf Katılım, FKS., 6;Türkiye Finans, FKS., 6; Ziraat Katılım, FKS., 6.1). Ayrıca bu ifadeler İslami finansın bir varlık üzerinden ticari bir faaliyet olarak gerçekleşmesi gerekliliğine de aykırıdır.

Aynı maddenin devamında "Bu sebeple Kiralayan, mala ilişkin ayıplardan, teslimden, alınması gereken izinlerin alınmamasından, malın taşınmasından, cana veya 3. Şahıslara ait mallara veya çevreye verdiği zararlardan vs. mevzuatın malın satıcısına, sağlayıcısına, üreticisine veya alıcısına yüklediği sorumluluklardan hiçbir şekilde sorumlu değildir" (Vakıf Katılım, FKS., 6;Türkiye Finans, FKS., 6; Ziraat Katılım, FKS., 6.1) diyerek ayrı bir çelişki ortaya koymaktadırlar. Zira ilgili maddenin baş tarafında mevzuatı gerekçe gösteren Katılım bankaları, aynı maddenin devamında mevzuatın kendilerine yüklediği sorumluluklardan da sorumlu olmayacaklarını bu sözleşmeyle garantiye almaktadırlar. Hâlbuki finansal kiralamayı kira akdi üzerinden tanımlayan Katılım bankalarının, akde konu olan malı müşteriye satıncaya kadar yani kira süresince mülkiyet riskini üstlenmeleri gerekmektedir. Zira bu, elde edilecek kârın meşruiyetiyle doğrudan bağlantılıdır. Bu nedenle biz finansal kiralamayı mülkiyet bağlamında taşıdığı risk açısından değerlendireceğiz.

\section{Mülkiyet Kaynaklı Risk}

Hz. Peygamber'in nimet ve külfet dengesine riayet edilmesi gerektiğini ifade eden "el-harâc bi'd-damân" (Tirmizî, Büyû, 53; Ebû Dâvûd, Büyû, 71) ve riskine katlanılmayan kârın meşru olmadığını ifade eden "ribh ma la yudman" (Ebû Dâvûd, Büyû, 68; Nesâî, Büyû, 60; Tirmizî, Büyû, 19) hadislerini delil alan İslam hukukçuları kazancın meşruiyetinde mülkiyetin riskine katlanmanın zorunlu olduğunu ifade etmişlerdir. Finansal kiralamada malın mülkiyetinin kendilerine ait olduğunu açıkça belirten Katılım bankalarının akde konu olan malı vekâlet yoluyla sahiplenmeleri bu sonucu değiştirmemektedir. Zira vekilin ister kendi namına isterse müvekkili namına yaptığı tasarruflarda, üçüncü şahısların talep edecekleri hak ve alacakların muhatabı olması konusunda farklı görüşler ileri sürülmüş olsa da yapılan işlemlerin hukuki sonucunun müvekkili bağlayacağı hususunda İslam hukukçuları ittifak halindedirler. (Karaman, 1991, II, 349; Zuhaylî, 1989, IV, 163). Dolayısıyla finansal kiralamada bankanın vekili olan kiracı, malı kabzettiği andan itibaren mülkiyete ait tazmin sorumluluğu mal sahibi olan bankaya intikal etmektedir. Bankanın da bu sorumluluğu yüklenmesi gerekmektedir. Biz bankanın yüklenmesi gereken tazmin sorumluluğunu a) mülkiyetin gerektirdiği telef ve hasar sorumluluğu b) malın aslına yönelik masrafları başlıkları altında inceleyeceğiz.

\section{a. Malın Telef ve Hasar Sorumluluğu}

Katılım bankaları finansal kiralamaya konu olacak malın, müşteri tarafından bulunarak malın cinsi, vasfi ve niteliklerinin bankaya bildirilmesi sonucu finansal kiralamanın 
yapıldığını, bu nedenle mala ait bütün sorumluluğun kiracıya ait olduğunu ifade etmektedirler. Bu durum sözleşmelerinde şu şekilde belirtilmiştir.

"Kiralananı ve satıcıy bulan, öneren kiracı olmakla, kiralananın tesliminden, ayıp ve zaptından doğan tüm sorumluluk garantör sıfatıyla kiractya aittir; bu hususlarda kiralayanın hiçbir sorumluluğu söz konusu değildir. Kiracı, konuya ilişkin haklarından peşinen ve gayrikabili rücu feragat etmiştir." (Kuveyt Türk, FKS., 14; Vakıf Katılım, FKS., 15.2.2; Ziraat Katılım, FKS., 12.1).

Ayrıca Katılım bankaları malın teslim edilememesi halinde de müşterinin hiçbir talepte bulunamayacağını sözleşmelerinde beyan etmektedirler.

"Kiracı kiralayana karşı, üreticinin/satıcının kiralananı teslim etmemesi, geç teslim etmesi, kiralananın kararlaştırılan nitelik, nicelik, cins ve özelliklere uymaması, üçüncü kişilerin kiralanan üzerinde veya kiralanan ile ilgili olarak hak iddia etmeleri veya kiralananın bozukluğu sebebiyle veya benzeri nedenlerle hiçbir ad altında bir talepte bulunamaz, kiralar ödememe veya geçödeme yoluna gidemez, kiralayanın sözleşme ve eklerinden doğan haklarını kullanmasına engel olamaz."(Kuveyt Türk, FKS., 14; Vakıf Katılım, FKS., 15.2.2; Türkiye Finans, FKS., 15.2.2; Ziraat Katılım, FKS., 12.2).

Sözleşmelerdeki bu şartlar İslam hukuku açısından incelendiğinde Katılım bankalarının, mülkiyetin gerektirdiği telef ve hasar sorumluluğunu yüklenmedikleri açıkça görülmektedir. Hatta Katılım bankalarının kiralanan şeyin teslim edilememesi ya da geç teslim edilmesi veya üçüncü şahısların hak iddia etmeleri durumunda kira talep etmelerinin İslam hukuku açısından izahı mümkün gözükmemektedir. Zira "Menfaatin bedel karşılığında temliki"(Ali Haydar Efendi, 1991, I, s. 439) olarak tanımlanan kira akdinin hukuki sonucu kiralayanın kiraya konu olan aynı, akdin gerektirdiği şekilde kiracıya teslim etmesidir. Menfaatin peyderpey ortaya çıktığı kira akdinde teslim, kiralanan aynın kiracının kullanımına hazır hale getirilmesi ve kullanımı engelleyen durumların ortadan kaldırılmasıyla gerçekleşir. (Kâsânî, 2003, V, s. 537; İbn Abidin, 1992, VI, s. 79-80; Karâfî, 1994, V, s. 493; Şirazî, 1995, II, s. 253-254; İbn Kudâme, 1984, VI, s. 36; Zuhaylî, 1989, IV, s. 765).

Kira akdi belirli bir varlık üzerinde yapıldığında o varlık kiracıya menfaatinden istifade edecek şekilde teslim edilmediği sürece kiralayanın ücreti hak etmesi söz konusu değildir. Aynı zamanda bu durum akdin fesh edilme gerekçesidir. (Karâfî, 1994, V, s. 476). Buna göre akitten sonra kabızdan önce ya da kabızdan sonra malın menfaatinden istifade etmeden önce ayn telef olursa kira akdi infisah olur. Dolayısıyla kiralanan aynın menfaatinden yararlanma imkânının tamamen veya kısmen ortadan kalkması durumunda elde edilecek kazanç, haksız kazanç olduğundan meşru değildir. Ancak menfaatinden istifade edilecek bir süre geçtikten sonra mal telef olursa o süre miktarınca ücret hak edilmiş olur. (Kâsânî, 2003, VI, s. 25-26; İbn Abidin, 1992, VI, s. 77-78; Karâfî, 1994, V, s. 413; Şirazî, 1995, II, s. 261-262; İbn Kudâme, 1984, VI, s. 35). Akit anında bilenmeyen bir ayıbın malda bulunması halinde ise kiracı, akdi fesh etme ya da akdi o haliyle kabul etme arasında muhayyerdir. Şayet kiracı ayıplı malı kabul ederse Hanefî, bir görüşte Şafiî ve Hanbelîlere göre kirayı tam olarak ödemesi gerekir. Malikî ve bir görüşte Şafiîlere göre ise ayıp nispetinde kiradan düşürme hakkına sahiptir. (Kâsânî, 2003, VI, s. 25-26; İbn Abidin, 1992, VI, s. 77; Şirazî, 1995, II, s. 261-264; İbn Kudâme, 1984, VI, s. 35-36).

Yine İslam hukukuna göre kiracının elinde mal emanet hükmündedir, ihmal ve kusuru olmadıkça malın hasar ve telefinden sorumlu değildir. Kiralayanın bu sorumluluğu kiracıya 
yönelik bir şart olarak ileri sürmesi ise kira akdinin doğasına aykırı olması ve bir yönüyle kira akdinin emanet akdi olması nedeniyle genel kabule göre caiz değildir. (İbn Kudâme, 1984, VI, s. 37-38; Ali Haydar Efendi, 1991, I, s. 697). Malikî mezhebinde konuyla ilgili üç farklı görüş ileri sürülmüştür. Meşhur olan görüşe göre bu şart akdin muktezasına aykırı olduğu için geçerli değildir. Eşheb el-Kaysî’ye (ö.204/820) göre ise geçerlidir. Üçüncü görüş göre ise kira akdinde geçerli olmayıp rehin ve iâre akitlerinde geçerlidir. (Karâfî, 1994, V, s. 505). Yine bir rivayette Ahmed b. Hanbel'e (ö.241/855) göre kira akdinde bu şart geçerlidir. (İbn Kudâme, 1984, VI, s. 131-132). Klasik dönemdeki bu görüşleri dikkate alan Muhyiddin Ali Karadâğî, İslam Fıkıh Akademisi'nin XII. Döneminde finansal kiralamayla ilgili sunduğu tebliğinde bu şartların ileri sürülebileceğini belirtmiş olsa da (Karadâğ̂̀, 2000, XII/I, s. 541) müzakereler kısmında tebliğindeki ifadelerine açılık getirerek İslami bankalar tarafından uygulanan finansal kiralamanın normal kira akdi olmadığını, bu nedenle tazmin sorumluluğunun bankadan kaldırılmasının faiz şüphesini içereceğini ve bu tür şartların ileri sürülemeyeceğini açıcça ifade etmiştir.(Karadâğ̂̂, 2000, XII/I, s. 661).

Nitekim İslam Fıkıh Akademisi III. Dönem toplantısında aldığ 1 kararında; “Kiracının kasıt ve kusuru olmadıkça malın telef olması ve ayıplı hale gelmesi durumlarında sorumluluk mal sahibi olarak bankaya aittir." Yine XII. Dönem toplantısının 3 nolu kararında; "Kiralanan malın tazmin yükümlülüğ̈̈ kiractya değil, kiraya verene (bankaya) ait olmalıdır. Buna göre kiracının kastı ve ihmali olmaksızın meydana gelen hasarlar kiraya veren tarafindan karşılanmalı, kiracı da elde edemediği menfaat karşılığında bedel ödemek zorunda bırakılmamalıdır" diyerek bu hususu açıkça ifade etmiştir.

Faizsiz Finans Kuruluşları Muhasebe ve Denetim Organizasyonu'nun (AAOIFI) şer'î standartlarının ilgili maddelerinde bu durum şu şekilde ifade edilmiştir.

5/1/5-Kiralayanin, kira konusu varliktan yararlanmayı engelleyen kusurlardan veya kendi fiiliyle ya da iradesi dışındaki herhangi bir sebeple kira konusu varlıkta meydana gelecek ve kullanımını olumsuz etkileyecek unsurlardan sorumlu olmama şartı ileri sürmesi caiz değildir.

5/1/8-Kiracının kasıtlı veya kusurlu bir davranışı olmadığı sürece kira konusu varlıkla ilgili hasar yükümlülü̆ğ̈̈ (damân), kira müddeti boyunca kiralayana aittir.

7/1/4-Kira konusu varlık, kiracının nezdinde emanettir. Bu yüzden kasıt veya kusuru bulunmadı̆̆ı sürece kiracı bu varlığın tazmin edilmesiyle yükümlü olmaz. Ancak kira konusu varlık kiracının kasıt veya kusuru dolayısıyla telef olmuşsa tazmin yükümlülü̆̆̈̈ doğar.

\section{b. Mala Ait Masraflar}

Katılım bankaları finansal kiralamaya konu olan malın telef ve hasar sorumluluğunu kendileri yüklenmeyip müşterilerine yükledikleri gibi mala ait bütün masrafları da müşterilerine yüklemektedirler. Bu durum sözleşmelerinde şu şekilde ifade edilmiştir.

"Malın her türlü olağan ve olağanüstü bakımı, tamiri, korunması ve bunlarla ilgili tüm işçilik, yedek parça, nakliye, muayene vs. her türlü masraf ve ücret kiractya aittir." (Kuveyt Türk, FKS., 18; Türkiye Finans; FKS., 15.6.1; Vakıf Katılım, FKS., 15.6; Ziraat Katılım, FKS., 16).

Yine malın aynına yönelik bütün vergi, resim, harç ve masrafların kiracıya ait olduğu ifade edilmiştir.

“Sözleşmenin devamı müddetince kiralananın aynından kaynaklanan/kaynaklanacak her türlü vergi, resim, harç ve masraf ile kiracının sözleşme sonunda satın alma seçeneğini kullanması halinde, devirle 
ilgili her türlü vergi, resim, harç ve masraf da (yeniden değerleme sebebiyle meydana gelecek artışlar vs. dahil) kiracıya aittir. Kiracı, söz konusu vergi, resim, harç ve masrafların ödendiğine dair belgeleri ilgili dönemlerde kiralayana sunmakla yükümlüdür. Kiracmm bunlar ödemeden sarfinazar etmesi durumunda kiralayan bu bedelleri ödeyerek kiracının borcuna ilave edebileceği gibi; dilerse sözleşmeyi feshetme hakkına da sahiptir." (Kuveyt Türk, FKS., 6.7; Türkiye Finans, FKS., 20; Vakıf Katılım, FKS., 20.7; Ziraat Katılım, FKS., 8.9).

Sözleşmelerde ileri sürülen bu şartlar İslam hukuku açısından incelendiğinde Katılım bankalarının mala ait masrafları yüklenmedikleri görülmektedir. Zira İslam hukukuna göre kira konusu olan mala yönelik masraflar ya malın aynını muhafazaya yöneliktir ya da kullanım kaynaklıdır. Eğer masraflar demirbaşa ait temel giderlerden veya akde konu olan malın menfaatini kullanamama kaynaklı ise "el-harac bi'd-damân" (Mecelle, md. 85) kuralı gereği bu tür masraflar kiralayana, kullanımdan kaynaklı ise kiraciya aittir. (Serahsî, 1982-83, XV, s. 157; Şirazî, 1995, II, s. 254; Ali Haydar Efendi, 1991, I, s. 608-609). Çünkü kiralayan, kiralanan varlığın kullanılabilir halde bulundurulmasından yani menfaatin bekasından sorumlu olan taraftır. Bu da kiralanan varlığın sağlam bir şekilde tutulmasına ve gerekli onarımlarının yapılmasına bağlıdır. Zaten kiralayanın kira ücretini hak etmesi de kiracıya sunmuş olduğu bu menfaatin karşılığıdır. (Heyet, ts., s. 261). Hatta İslam hukukçularının çoğunluğuna göre kiralayanın malın aslına yönelik tamiratı gerçekleştirmemesi halinde kiracının akdi feshetme hakkı vardır. (İbn Abidin, 1992, VI, s. 46-47; Şirazî, 1995, II, s. 261; İbn Kudâme, 1984, VI, s. 37; Heyet, 1993, I, s. 286). Bu masrafların kiracıya şart olarak sürülmesi bütün mezheplere göre akdin fasid olma gerekçesidir. Zira bu durum, ücretin meçhul olmasina neden olmaktadır. (Heyet, 1993, I, s. 286). Ali Haydar Efendi (ö.1935) vergi masraflarının da kiralayana ait olduğunu, bu vergilerin devlet tarafından kiracıdan alınması halinde kiracının kiralayana -izni olmasa dahi- rücu etme hakkının olduğunu ifade etmektedir. (Ali Haydar Efendi, 1991, I, s. 611).

Nitekim İslam Fıkıh Akademisi XII. Dönem toplantısının 6 nolu kararında “Akde konu olan malın işletilmesinden kaynaklanan masraflar dışında kalan malın aslına yönelik servis masraflarının kiraya veren tarafindan karşılanması gerektiği" belirtmiştir. Yine AAOIFI'nin 5/1/7 maddesinde "Kiralayanın, kira konusu varlığın kullanılmaya elverişli hâlde kalması için zorunlu olan esaslı bakımlardan kiracının sorumlu olacağı şartın ileri sürmesi caiz değildir. Ancak kiralayan, bakım masraflarının kendi hesabına olacak şekilde yapılması için kiracısına vekâlet verebilir. Kira konusu varlıkla ilgili işletme veya mutat dönemsel bakım masrafları kiracıya aittir" ifadesi yer almaktadır.

Malın aynına yönelik masraflardan biri de malın sigortalanma zorunluluğudur. Sözleşmelerde bu şu şekilde ifade edilmiştir.

"Kiracı, kiralananı ve teminatları kiralayan adına, muhtemel tüm risklere ve olağanüstü hallere karşı gerekli tüm şart ve klozlarla sigorta ettireceğini ve sigorta ile ilgili tüm prim ve masraflarla, gider vergilerini ödeyeceğini, sigorta sürelerinin bitmesi halinde aynı şekilde tüm risklere karşı sigortayı yenilettireceğini gayrikabili rücu kabul, beyan ve taahhüt eder. Sigorta primlerinin ödenmesi ile ilgili her türlü sorumluluk kiracıya aittir. Kiralayan gerekli gördüğ̈̈ takdirde, tüm masraflar Kiractya ait olmak ve kira bedeline dahil edilmek üzere sigorta yaptırabilir; bunlarla ilgili prim ve masraflar Kiract hesabına (kira bedeline ilave ederek) resen borç kaydeder. Sigorta sözleşmesinden doğan tazminatlar doğrudan Kiralayana ödenir." (Kuveyt Türk, FKS., 19; Vakıf Katılım, FKS., 15.7; Türkiye Finans, FKS., 15.7.1; Ziraat Katılım, FKS., 17.1). 
Sözleşmelerde ileri sürülen sigorta şartı İslam hukuku açısından incelendiğinde Katılım bankalarının mala ait bu sorumluluğu yüklenmedikleri görülmektedir. Zira sigorta malın aynına yönelik bir tedbirdir. Dolayısıyla mal sahibi olan bankanın "risk-getiri dengesi" ilkesi bağlamında mülkiyetin riskine katlanarak finansal kiralamaya konu olan malın sigorta primlerini ödemesi gerekmektedir. (Takî Osmânî, 2013, I, s. 205; Karadâğ̣̂i, 2000, XII, I, s.661). Banka bunu kira taksitlerine yansıtma hakkına da sahiptir. (Karadâğî, 2000, XII, I, s.661). Ayrıca Katılım bankalarının sigorta primlerini kiracıya şart olarak koşmasının finansal kiralama akdinin özünü etkileyeceği de göz ardı edilmemelidir. Sözleşmelerde dikkat çeken bir başka nokta ise şudur. Primlerin kiracı tarafından ödenmesi şartını ileri süren Katılım bankaları, Sigorta sözleşmesinden doğan tazminatlar doğrudan kiralayana ödenir ifadeleri ile ödemedikleri primlerin kendilerine ödenmesi şartını ileri sürerek haksız kazanç elde etmektedirler. Bu durum kiracıyı iki yönden mağdur etmektedir. Bunlardan biri finansal kiralamada satış dikkate alınarak kira bedelinin yüksek tutulması, diğeri ise sigorta primlerini yatıran kiracının bu tazminattan faydalanamamasıdır. (Gönenç, 1997, s. 266). İleri sürülen bu şartlar ticari etik açısından uygun olmamanın ötesinde Katılım bankaları tarafından uygulanan finansal kiralamanın yapısına da aykırıdır.

Nitekim İslam Fıkıh Akademisi'nin III. ve XII. Dönem kararlarında sigorta sorumluluğunun mal sahibine ait olacağ 1 ifade edilmiştir. AAOIFI'nin 5/1/8 maddesinde de sigorta sorumluluğunun bankaya ait olduğu şu şekilde ifade edilmiştir. "Kiralayanın, bu varlığı gerekli masraflar kendisine ait olmak üzere, eğer imkân varsa, tekâfül yöntemiyle sigortalaması caizdir. Kiralayan, kira ücretini yapmış olduğu sigorta masraflarını göz önünde bulundurarak belirleyebilir. Ancak kira sözleşmesi kurulduktan sonra bu tür masrafların kiractya yüklenmesi yani kira ücreti belirlenirken tespit edilen ücrete ek olarak herhangi bir masrafin kiracıdan alınması caiz değildir. Kiralayan, masraflar kendi hesabına olacak şekilde sigorta yapılması için kiracısına vekâlet verebilir."

Görüldüğ̈̈ üzere İslam hukukunda finansal kiralamanın ötesinde kira akdinde dahi mülkiyet kuralı gereği mala ait risklerin yani malın telef ve hasar sorumluluğu ile malın aslına yönelik bakım ve sigorta masraflarının mal sahibine ait olmasının gerekliliği ifade edilmiştir. Bu gerekliliğin arkasında a) risk-getiri dengesi ilkesi, b) akdin muktezasının gereği, c) kira akdinin çift yönlü olması yani bir yönüyle emanet akitlerden olması, d) kira bedelinin meçhul olmaması gibi gerekçeler bulunmaktadır. Hâlbuki bunların tamamını göz ardı eden Katılım bankaları finansal kiralamada, salt bir kira akdi yapmayıp kira akdi üzerinden finansman sağlamaktadırlar. Katılım bankalarının mülkiyete ait olan bu riskleri sözleşmelerinde hiçbir ayırım yapmadan kiracıya yüklemeleri yukarıda zikredilen gerekçeleri ihlal etmekle birlikte finansal kiralama akdinin özünü etkilemektedir. Bu durum haklı olarak Katılım bankalarının yaptıkları eylemlerin sorgulanmasına neden olmaktadır. $\mathrm{Bu}$ sebeple biz, Katılım bankalarının finansal kiralamada mülkiyete ait riskler hususunda daha hassas davranmaları gerektiği kanaatindeyiz.

\section{Değerlendirme Ve Sonuç}

Klasik dönemde mevcut olmayıp son dönemlerde ortaya çıkan akit çeşitlerinden biri olan finansal kiralamaya yönelik farklı fıkhî tasavvurlar ortaya konmuştur. Bu tasavvurlar incelendiğinde, malın mülkiyetinin müşteriye intikali ile sonlanan bu akdin, vadeli satış olarak veya kira akdi olarak başlayıp satış veya hibe akdi olarak sonlanan mürekkeb bir akit 
olarak ya da kira ve satış akdinden karma yeni bir akit olarak fıkhî değerlendirilmeye tabi tutulduğu görülmektedir.

Bunlar içerisinde yaygın olan finansal kiralamanın kira temelli olarak başlayıp sonra müstakil bir akitle sonlandığı görüşüdür. Bu görüşe göre kiralayanın, mülkiyet kuralı gereği malın tazmin yükümlülüğünü ve aynı zamanda malın aslına yönelik bakım masraflarını yüklenmesi kira akdinin gereğidir. Dolayısıyla bunların kiracıya şart olarak ileri sürülmesi uygun değildir.

Finansal kiralamayı kira temelli bir akit olarak kabul eden Katılım bankalarının finansal kiralama sözleşmeleri incelendiğinde mülkiyete ait riskleri yüklenmedikleri görülmektedir. Hatta bunun ötesinde mevzuatın boşluklarını dahi kendi lehlerine kullandıkları müşahede edilmektedir. Örneğin ilgili kanunun 24/3 maddesinde "Sözleşmede aksine hüküm yok ise kiracı, malın her türlü bakımından ve korunmasından sorumlu olup, bakım ve onarım masrafları kiracıya aittir" denilerek "aksine hüküm yoksa" kaydıyla taraflara bir serbestlik verildiği halde Katılım bankalarının bu serbestlikten istifade ederek sözleşmelerinin bazı şartlarını temel ilkelerine uygun hale getirmedikleri görülmektedir. Bununda ötesinde Katılım bankalarının bu serbestliği temel ilkelerine aykırı olarak kiracı aleyhine yorumlamaları hayreti muciptir.

Katılım bankalarını geleneksel bankalardan ayırt eden en önemli hususlardan birisi finansal faaliyetlerini kredi üzerinden gerçekleştirmemeleridir. Mevzuat açısından da mümkün olmayan bu durum Katılım bankalarının kuruluş felsefelerine de uygun düşmemektedir. Katılım bankaları finansal kiralamayı mevzuatın kendilerine verdiği yetkiye dayanarak ticaret üzerinden gerçekleştirmektedirler. Bu durum "el-harac bi'd-damân” kuralı gereği ticaretin riskine yani mülkiyetin riskine katlanmayı gerekli kılmaktadır. Riskten arındırılmış bir finansal faaliyetin faiz şüphesini barındıracağı açıktır. Bu sebeple Katılım bankalarının finansal kiralama sözleşmelerini geleneksel finansal kiralamayı esas alarak düzenlemelerinin uygun olmadığı kanaatindeyiz. Teoride düşünülenin pratiğe yansıtılmaması Katılım bankaları hakkındaki kanaatleri zedelemektedir. Mevzuatın etkisinin de olduğunu düşündüğ̈̈müz bu konuda sözleşmelerin yeniden yapılandırıldığı bu dönemde daha hassas davranılacağı ümidini taşımaktayız.

\section{Kaynakça}

Abadî, A. (2000). “et-Ta'kib ve'l-münakaşa”, Mecelletü Mecmaı'l-fıkhi'l-İslâmî, Cidde: Münazzametü'l-Mü'temeri'1-İslâmî, XII, (I), ss. 647-649.

Abdullah, M. A. (1988). "et-Te'cîru'1-müntehiye bi't-temlîk ve's-suveru'l-meşrûa'tu fîhi", Mecelletü Mecmar'l-fikhi'l-İslâmî, Cidde: Münazzametü'l-Mü'temeri'l-İslâmî, V, (IV), ss. 2595-2606.

Aktepe, İ. E. (2013). Sorularla Katılım Bankacılığı, İstanbul: TKBB Yayınları.

Aktepe, İ. E. (ts.). Katılım Finans, İstanbul: TKBB Yayınları.

Ali Haydar Efendi, (1991). Dürerü'l-hükkâm şerhi Mecelleti'l-Ahkâm, ta'rib. Fehmi elHüseynî, I-IV, Beyrut: Dâru'l-Cîl.

Bayındır, S. (2005). İslam Hukuku Penceresinden Faizsiz Bankacılık, İstanbul: Rağbet Yayınlar1. 
Desûkî, Ş. (ts.). Haşiyetü'd-Desûkî ala Şerhi'l-Kebîr, (Muhammed Aliş şerhiyle beraber), I-IV, Mısır: Matbaatü İsa Halebî ve Şürekâuhu.

Gönenç, H. (1997). Faiz ve Finans ve Borsa ile İlgili Bazı Meseleler, I. Uluslar Arası Ticaret Hukukunun Günümüzdeki Meseleleri Kongresi, Konya: KOMBAD Yayınları, ss.257-270.

Hammad, N. (2001). Kadâyâ fıkhıyye muasıra fi'l-mâl ve'l-iktisâd, Dımaşk: Dârü'l-Kâlem.

Heyet, (1993). el-Mevsûatü'l-fıkhıyye, I-XXXXV, Kuveyt: Vüzaretü'l-Evkaf ve'ş-şuûni'lİslamiyye.

Heyet, (ts.). Faizsiz Finans Standartları, İstanbul: TKBB Yayınları.

Haraşî, M. (1317). Haraşî ala Muhtasarı Halil (el-Adevî haşiyesi ile birlikte), I-VIII, Mısır: elMatbaatü'l-Emirriye el-Kübrâ.

İbn Abidin, M. E. (1992). Haşiyetü Reddi'l-Muhtar, I-VIII, Beyrut: Dârü'l-Fikr.

İbn Kudâme, M. (1984). el-Muğnî, I-XIV, Beyrut: Dâru'l-Fikr.

İbn Rüşd, E. V. (2004). Bidâyetü'l-müctehid ve nihâyetü'l-muktesıd, thk. Ferid Abdülaziz elCindiyyü, I-IV, Kahire: Dâru'l-Hadis.

İmranî, A. (2006). el-Ukudü'l-maliyye el-mürekkeb dirase fıhkıyye ta'sıliyye ve tatbıkiyye, Riyad: Daru Kunuz İşbiliyye.

İnanır, A. (2017). “İslam Hukuk Düşüncesinde Bileşik (Mürekkep) Malî Sözleşmeler”, Uluslararası İslam Ekonomisi ve Finansı Araştırmaları Dergisi, 3, (1), Mart ss. 7-39.

Kacır, T. (2020). İslam Hukukunda Kazancın Meşruiyetine Etki Eden Risk Faktörü (Katılım Bankacılığı Uygulamaları Örnekliğinde). Süleyman Demirel Üniversitesi İlahiyat Fakültesi Dergisi, XXXXIV, (1), ss. 139-152.

Kahf, M. (2000). el-İcare el-müntehiye bi't-temlîk ve sukûkü'l-a'yan el-müeccere, Mecelletü Mecmar'1-fıkhi'1-İslâmî, Cidde: Münazzametü'1-Mü'temeri'1-İslâmî, XII, (I), ss. 353-407.

Karadâğî, M. A. (2000). "el-İcâretü ve tatbîkâtuha el-muâsıra", Mecelletü Mecmai'l-fıkhi'lİslâmî, Cidde: Münazzametü'l-Mü'temeri'l-İslâmî, XII, (I), ss. 430-565.

Karadâğ̂̂, M. A. (2000). "et-Ta'kib ve'1-münakaşa”, Mecelletü Mecmaı'l-fıkhi'l-İslâmî, Cidde: Münazzametü'l-Mü'temeri'l-İslâmî, XII, (I), ss. 658-662.

Karâfî, Ş. (1994). ez-Zehîra, thk. Muhammed Buhubze, I-XIV, Beyrut: Darü'1-Garbi'1-İslâmî.

Karaman, H. (1991). Mukayeseli İslam Hukuku, I-III, İstanbul: Nesil Yayınları.

Kâsânî, E. A. (2003). Bedâiü's-sanâi' fi tertîbi'ş-şerâi', thk. Adil Ahmed Abdülmevcud-Ali Muhammed Muavvaz, I-X, Beyrut: Dârü Kütübi'l-İlmiyye.

Senhûrî, A. (1997). Mesâdirü'l-hak fî fikhi'l-İslâmî, I-II, Beyrut: Darü İhyâi et-Türâsi'l-Arâbî.

Serahsî, E. M. (1982-83). Kitabü'1-Mebsût, I-XXX, İstanbul: Çağrı Yayınları.

Şazelî, H. A. (1988). "el-İcâre el-müntehî bi't-temlîk", Mecelletü Mecmaı'l-fıkhi'l-İslâmî, Cidde: Münazzametü'l-Mü'temeri'l-İslâmî, V, (IV), ss.2609-2657.

Şeta, A. E. (1424). el-Muhâsebe an ukûdi'l-icâreti el-müntehiyeti bi't-temlik fî́l-mesârfi'lİslamiyyeti min manzûri İslamî, Cidde: el-Bankü'l-İslâmî li't-tenmiye.

Şevkânî, E. A. M. (1996). Neylü'l-evtâr şerhü Münteka'l-ahbâr, I-VIII, Dımaşk: Dâru'l-Hayr. 
Şirazî, E. İ. C. (1995). el-Mühezzeb fî fıkhi'l-imâm eş-Şâfiî, zabd ve tash: Zekeriyya Ömeriyat, I-III, Beyrut: Dârü'l-Kütübi'l-İlmiyye.

Takî Osmânî, M. (2013). Buhûs fî kadâya fıkhıyye muâsıra, I-II, Dımaşk: Darü'l-Kalem.

Takî Osmânî, M. (2000). "et-Ta'kib ve'l-münakaşa”, Mecelletü Mecmaı'l-fıkhi'l-İslâmî, Cidde: Münazzametü'l-Mü'temeri'l-İslâmî, XII, (I), ss. 644-645.

Uveyda, A. (2010). Nazariyyetü'l-muhâtâra fî'l-iktisâdi'l-İslâmî, el-Ma'hadü'l-'âlî li'l-fikri'lİslâmî, Beyrut: Mektebeü't-tevzî fî́l-Âlemi'l-Arabî.

Zuhaylî, V. (1989). el-Fıkhü'l-İslâmî ve edilletühü, I-VIII, Dımaşk: Dârü'l-Fikr.

Zuhaylî, V. (2002). el-Muamelâtü'l-maliyye el-muâsıra, Beyrut: Daru'l-Fikr. 